\title{
Evaluation of an Immuno-Chromatographic Detection System for Shiga Toxins and the E. coli 0157 Antigen
}

\author{
Ylanna Burgos and Lothar Beutin* \\ National Reference Laboratory for Escherichia coli, Unit 41: Microbial Toxins, \\ Federal Institute for Risk Assessment (Bundesinstitut für Riskobewertung BfR), Berlin,
}

Germany

\section{Introduction}

The production of Shiga toxins (Verotoxins) is a characteristic trait of some strains of Escherichia coli. Shiga toxin-producing Escherichia coli (STEC), also called Verotoxinproducing E. coli (VTEC), were first described by Konowalchuk et al. in 1977 by their cytotoxic activity on African green monkey kidney (Vero) cells (Konowalchuk et al. 1977). STEC of serotype O157:H7 were linked to cases of Haemorrhagic Colitis (HC) and to the consumption of STEC- contaminated meat of bovine origin for the first time in 1982 (Karmali et al. 2010; Riley et al. 1983). Since 1982, hundreds of outbreaks of disease caused by STEC O157 and non-O157 strains have been reported in different countries and geographical regions of the world. A growing number of genetic variants of Shiga toxins $1+$ 2 (Stx1 and Stx2) were identified and today more than 400 serotypes of E. coli strains isolated from human patients were found associated with Stx production (Scheutz and Strockbine 2005).

Some STEC serogroups such as O157, O26, O103, O111 and O145 were most frequently associated with outbreaks and with Haemorrhagic Colitis and Haemolytic Uraemic Syndrome (HUS) in human patients worldwide. Accordingly, these strains were designated as Enterohaemorrhagic E. coli (EHEC) (Nataro and Kaper 1998). Classical EHEC belonging to these serotypes are responsible for more than $80 \%$ of HUS cases in Europe and in the United States (Brooks et al. 2005; Eblen 2007; EFSA 2007; Karmali et al. 2003). As EHEC O157 was reported to be the most frequent and virulent EHEC type a number of diagnostic tools (indicator media, O157 antigen detection kits, specific O157 enrichment media and O157specific PCRs) have been developed for its specific identification (Frank et al. 2011). However, the recent outbreak of Enteroaggregative Haemorrhagic E. coli (EAHEC) E. coli O104:H4 in Germany indicates that serotypes other than O157 can suddenly become the most highly virulent human pathogens (Frank et al. 2011).

Healthy dairy and beef cattle are recognized as a major natural reservoir of EHEC and other STEC strains. There are more than 100 serotypes of STEC which have been also isolated

${ }^{*}$ Corresponding Author 
from other animals such as sheep, pigs, goats, deer, horses, dogs and birds (Gyles 2007). Humans become infected most frequently by consuming STEC-contaminated food of different kinds, but also waterborne infections and the direct transmission from STECexcreting animals or humans are frequent (Caprioli et al. 2005). By contrast, humans but not animals were identified as the reservoir for the newly emerging EAHEC O104:H4 strain (ECDC et al. 2011). Studies have shown that STEC infections are more frequent in the warmer months and that the serotypes that are implicated may vary from country to country (Beutin 2006; Gyles 2007).

\section{Genetic and functional diversity of Shiga toxins}

The Shiga toxin family consists of two major groups, Shiga toxin 1 (Stx1) and Shiga toxin 2 (Stx2). Shiga toxins are composed of two subunits. The active toxin subunit A (Nglycosidase $32-\mathrm{KDa}$ ) is linked to five B-subunits as a pentamer (7.7-kDa monomers). The toxin subunit $B$ is responsible for binding the toxin to GB3 or GB4 receptors on the eukaryotic cells. Stx1 and Stx2 are immunologically not cross-reactive and show themselves to be $55 \%$ different in their amino acid sequences (Muthing et al. 2009). A number of genetic variants were identified within the Stx1 and the Stx2 toxin families (Burk et al. 2003; Leung et al. 2003; Muthing et al. 2009). The variants differ in the amino-acid substitutions in their StxA and StxB subunits, which can have an influence on their toxicity and receptor-binding specificity (Muthing et al. 2009). The Stx1 group has been divided into the subtypes Stx1, Stx1a, Stx1c and Stx1d (Burk et al. 2003) (Figure 1).

Stx1 is produced by some species of Shigella (Scheutz and Strockbine 2005). Stx1a is frequently found in STEC from cattle and in food of bovine origin (Martin and Beutin 2011) and it is found in major EHEC strains causing HC and HUS in humans. Stx1c was found to be associated with non-bloody diarrhoea in humans and is frequent in STEC from goats, sheep and red deer (Friedrich et al. 2003; Martin and Beutin 2011).

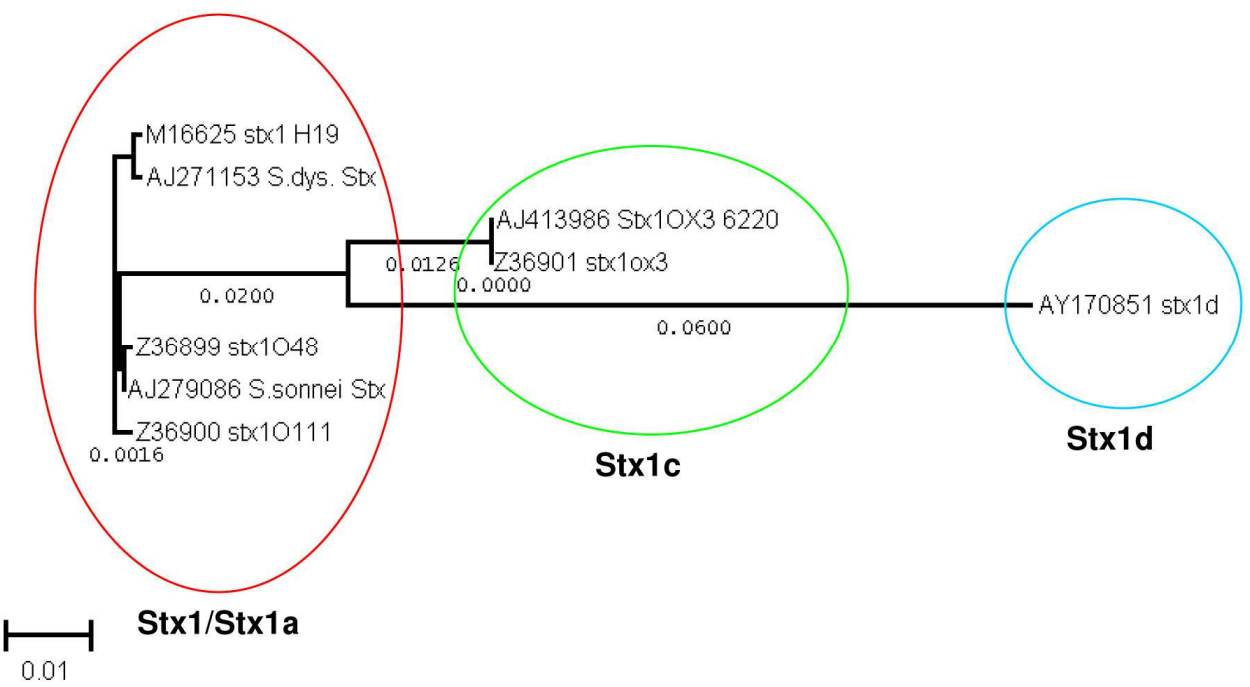

Fig. 1. Genetic distances within the group of Stx1 family toxins 
The Stx2 branch splits into the subgroups Stx2a, Stx2b, Stx2c, Stx2d, Stx2e, Stx2f and Stx2g (Persson et al. 2007) (Figure 2).

The infection of humans with STEC-producing toxin variants Stx2a, Stx2c and Stx2d(activatable) was associated with an increased risk of developing HC and HUS, while STECproducing Stx1c, Stx $2 b$ and Stx $2 f$ were found to be more associated with uncomplicated cases of diarrhoea or with asymptomatic infections (Friedrich et al. 2002; Persson et al. 2007). Stx1d- and Stx2g-producing STEC have been isolated from animals and food but the possible role of these toxins in human disease needs to be confirmed (Beutin et al. 2007a; Kuczius et al. 2004; Miko et al. 2009). Humans are rarely infected with Stx2e-producing strains (Friedrich et al. 2002). STEC-producing Stx2e are linked to pigs as a hosts and are agents of oedema disease in pigs. Aside from Stx2e, these strains frequently produce heatstable and heat-labile enterotoxins and Stx2e has not been shown to play a role as a virulence marker for humans (Beutin et al. 2008).

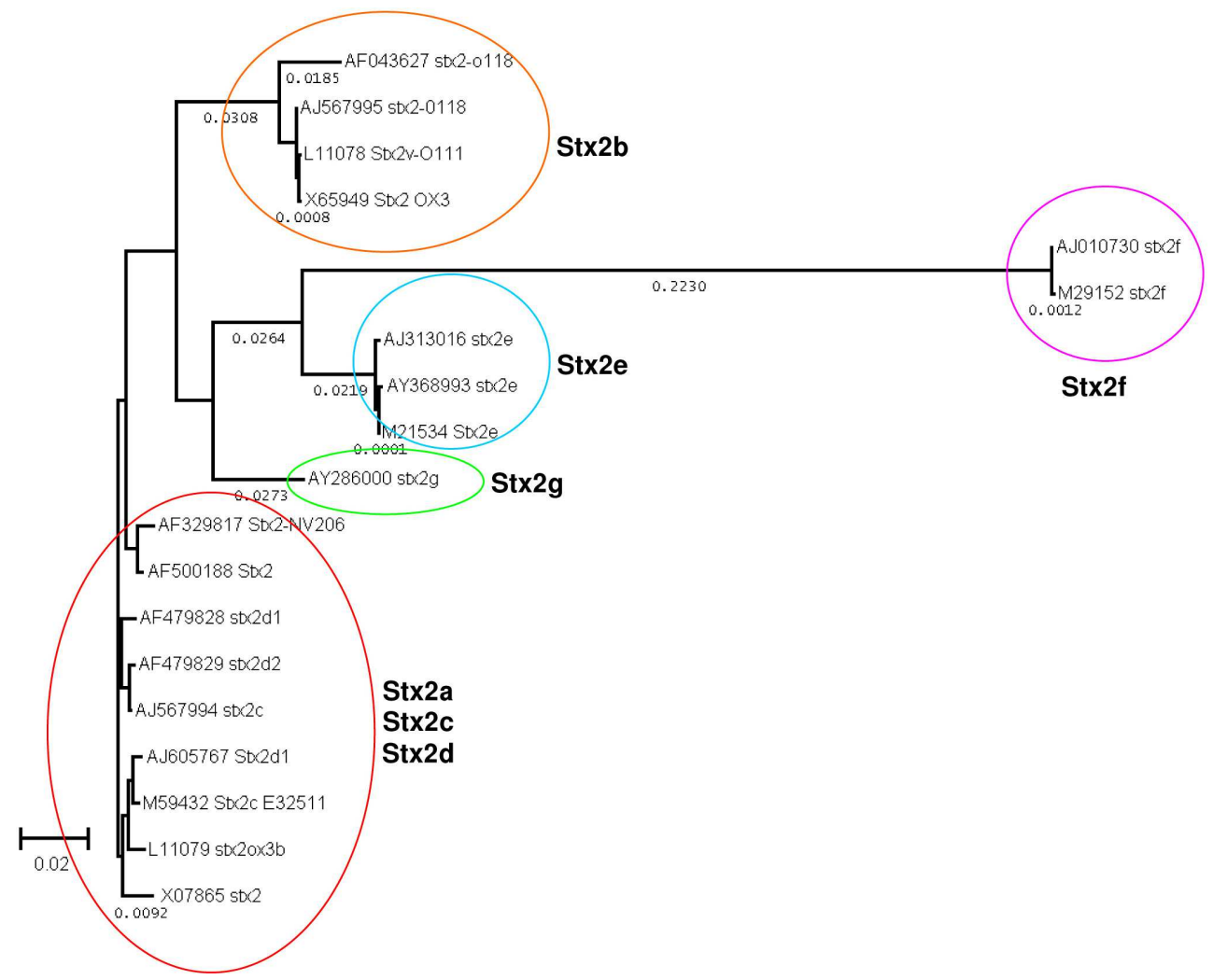

Fig. 2. Genetic distances within the group of Stx2 family toxins

The Shiga toxin genes are encoded by lambdoid bacteriophages which are integrated into the bacterial chromosome by lysogenization where they remain present as prophages (Schmidt 2001). Some kinds of physico-chemical stress can trigger a cascade reaction called bacterial "SOS response" leading to the transcription of the prophage genome, resulting in 
the production of both Shiga toxins and phage particles. The release of phages by bacterial lysis leads to the infection of new E.coli hosts and the generation of new STEC strains (Herold et al. 2004).

\section{Diagnosis of STEC by detection of Shiga toxins}

A number of indicator media for the identification of some STEC strains and types have been developed, as well as immunological, genetic and cell culture toxicity assays for Stxdetection. The detection of Shiga toxins is the only way to identify all members of the STEC group which consists of strains with different phenotypes and serotypes (Bettelheim and Beutin 2003). The Vero cell toxicity assay (VCA) is used as a gold standard for detection of Stx production as it is the most sensitive. However, its specificity must be confirmed in neutralization assays with antisera directed against Stx. As the VCA is laborious, timeconsuming and demands a specifically designed laboratory and specially trained personnel there is a need for STEC detection systems which are rapid, reliable, standardized and easy to employ. Almost all STEC testing methods screen for Stx production with commercial serological assays or the presence of stx-genes is detected using PCR or DNA-hybridization assays (Paton and Paton 2003).

Some STEC strains that were identified by stx-specific PCR failed to show serological reactivity in immunological detection systems for Stx (Beutin et al. 2007; Beutin et al. 2008). The lack of an Stx phenotype (serologically or cytotoxic) in a strain that tests positive when using stx-specific PCR may have several causes such as defective stx-genes, the absence of Stx expression, or the amount of Stx produced being below the detectable level of the given serological or cytological assay. Commercially-obtainable serological assays (EIA, RPLA) for Stx were found to vary greatly in their sensitivity (Bettelheim and Beutin 2003; Beutin et al. 2007; Beutin et al. 2010; Beutin et al. 1996; Beutin et al. 2002; Beutin et al. 2008; Feng et al. 2011; Jahn et al. 2008; Willford et al. 2009), and some STEC strains were found to produce low amounts of Stx, that were not detectable by tissue culture or serological tests. Previous work showed that about $1 \%$ of strains that carry stx-genes showed no production of Stx in the VCA as a gold standard (Beutin et al. 2007). A lack of Stx expression or low expression was found to be more frequent among certain stx-subtypes such as $s t x_{2 b}$, st $x_{2 \mathrm{e}}$ and stx $x_{2 \mathrm{~g}}$ (Beutin et al. 2007; Beutin et al. 2007a; Beutin et al. 2008). Another possible cause of these discrepancies between the presence of stx-genes and the absence of Stx production may be caused by the specificity of anti-Stx antibodies or stx PCR primers used for the identification of the various Stx subtypes (Feng et al. 2011).

Efforts to find reliable, specific and rapid methods for the detection of STEC have been increased over the last decades. Media containing inducing agents such as mTSB with Mitomycin $\mathrm{C}$ were used to trigger Stx production by bacteria for detection (Beutin et al. 2008; Klie et al. 1997; Shimizu et al. 2009). Some antibiotics such as trimethoprimsulfamethoxazole and ciprofloxacin were found to enhance Stx production by bacteria and may increase the risk of HUS when used as therapeutic agents in human infections with STEC (McGannon et al. 2010; Wong et al. 2000).

The detection of STEC can cause problems if food or clinical, animal and environmental samples that contain a mixture of different microorganisms are examined. Specific enrichment media are used for the recovery of injured STEC strains, which are often present 
in food and environmental samples. The bacteria may be stressed during the processing and storage of food. The enrichment procedure provides an optimal growth medium and a period of time that can be effectively used, allowing the resuscitation of the bacterial cells (Hussein and Bollinger 2008). The detection of stressed STEC from samples depends largely on the choice of the cultivation media and conditions. Non-selective media such as buffered peptone water were found to be advantageous for the resuscitation of damaged STEC from various samples (Hussein and Bollinger 2008; Jahn and Beutin 2009).

Stx detection kits such as enzyme-linked immunoassays (EIA) have been commercialized and are widely used as standardized assays in diagnostic laboratories. The evaluation of commercially available diagnostic test kits for Stx by E. coli reference laboratories has been shown to be valuable for the assessment of their specificity and sensitivity. In this work, we have evaluated an immuno-chromatographic lateral flow test for the detection of Shiga toxins and the E. coli $\mathrm{O} 157$ antigen which recently came on the market.

\section{Principle of the immuno-chromatographic lateral flow test system and test procedure}

The introduction of immuno-chromatographic lateral flow test systems has made Stx detection even quicker and simpler to perform than with the classical ELISA test. A specific photometer (ELISA-reader) is not necessary and the results are recorded by eye after 15 minutes. A new development allowing the simultaneous detection of Stx-production and of the $\mathrm{O} 157$ antigen (as the most important EHEC type) is the commercially available "RIDA Quick" test (RIDA ${ }^{\circledR}$ QUICK Verotoxin/O157 Combi, R-biopharm AG, Darmstadt, Germany).

The assay is bound to a plastic stick which is introduced with its absorbent end into the liquid sample containing Stx and O157 LPS as antigens. The principle of this assay is a single-step immuno-chromatographic lateral-flow test, where specific antibodies directed towards both target antigens are attached to red (Shiga toxin-specific) or green (O157specific) latex particles. Other specific antibodies against the two antigens are firmly attached to the membrane.

Modified Tryptic Soy Broth (mTSB) containing Mitomycin C (Klie et al. 1997) is inoculated with the test strain or sample and incubated at $37^{\circ} \mathrm{C}$ for 18 to 24 hours for the production of Shiga toxin. Mitomycin C serves as an enhancer to stimulate Stx-production and release in the culture fluid. After growth, the sample is centrifuged (1500g for 15 minutes) and $1 \mathrm{ml}$ of the supernatant fluid is diluted 1:1 with a sample buffer (part of the test system). The mixture is used directly for the test. The RIDA-QUICK test stick is placed into the test sample and the reaction occurs by the lateral flow of specific antibodies bound to coloured latex particles. Antibodies bind themselves to specific antigens (Stx and/or O157 LPS) if present in the sample and the antigen-antibody complex flows via the membrane to specific collection bands where they are fixed by immobilized, specific antibodies. A green (O157 LPS) and/or red (Stx) band becomes visible if these antigens are present in the sample. The test does not differentiate between Stx1 and Stx2. A blue band is always shown as a control. The coloured bands become visible after 15 minutes and the strength of the reaction is rated between 0 (not visible) and $4+$ (maximum colour development), according to colour 
intensity (Figure 3). A description is provided by the producer and the assay was performed accordingly (http://www.r-biopharm.de/).

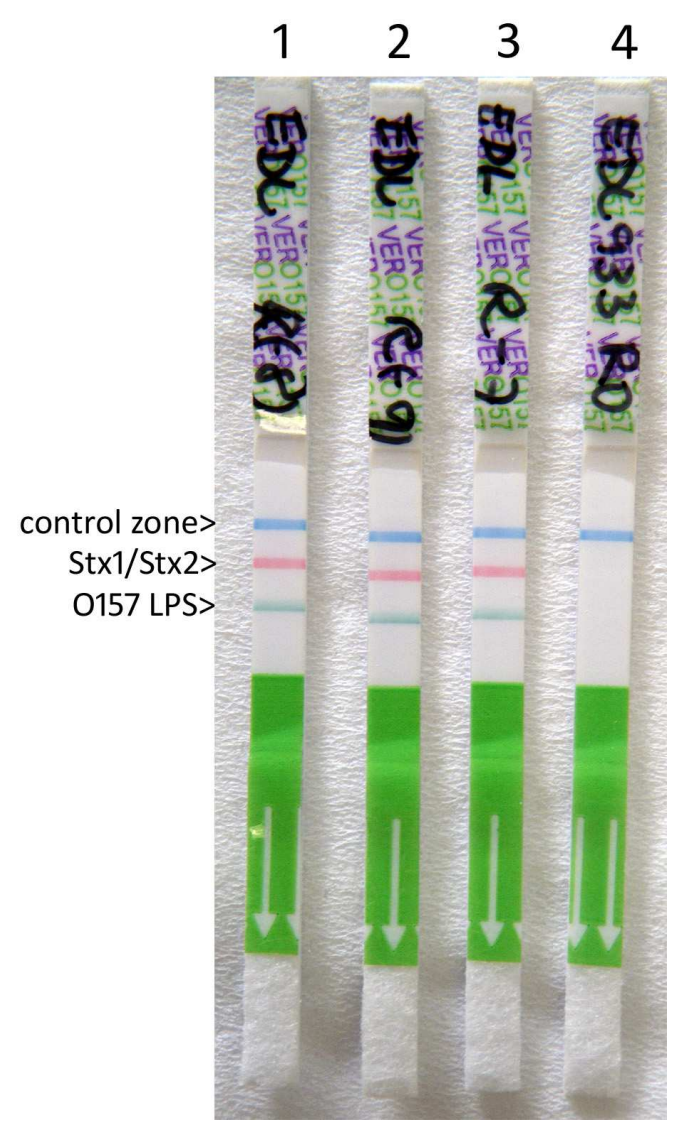

Fig. 3. Detection of Stx production and the O157 antigen from enrichment cultures of salad samples inoculated with different quantities of EHEC O157 strain EDL933.

\section{Results}

\subsection{Evaluation of the RIDA®QUICK Verotoxin/O157 Combi (Rida Quick) test with Shigella and $E$. coli reference strains}

We have evaluated the RIDA Quick test for its sensitivity and specificity with all the known variants of Stx1 and Stx2. For the evaluation, we employed STEC references strains for the different Stx-types and subtypes together with STEC isolates from food and other sources that were previously characterized at the NRL-E.coli at the BfR (Beutin et al. 2007a; Miko et al. 2009). The RIDA Quick was compared for its sensitivity and specificity with the Ridascreen ${ }^{\circledR}$ Verotoxin enzyme immunoassay (R-Biopharm, Darmstadt, Germany), and Stxspecific ELISA which was evaluated previously (Beutin et al. 2007). The Vero cell toxicity test was used as a gold-standard for toxin activity. 
In total, two strains of Shigella dysenteriae and S. sonnei (Stx1) and 18 E. coli-producing toxins of the Stx1 family (Stx1 (n=2), Stx1a $(n=9)$, Stx1c $(n=5)$ and Stx1d $(n=4)$ were tested. The RIDA Quick detected all strains of the Stx1 family (sensitivity of 100\%). All the reactions were $4+$, except for Stx1d strains showing reaction intensities between $1+$ and $3+$. Similar results were obtained with the Ridascreen-Stx-EIA (Beutin et al. 2007, this work).

Fifty-five strains were tested as representatives of the Stx2 family. The results were very good for the Stx2a (12/12 positive) and Stx2c (6/6 positive). Stx2b, formerly called Stx2d non-activatable (Pierard et al. 1998) was detected in 8 of 9 strains tested (88.9\%). The mucusactivatable Stx2d (Melton-Celsa et al. 2002) was detected in 5 of 7 positive strains $(71.4 \%$ ). The Stx2e variant was detected in only 3 of 11 Stx2e strains (27.3\%) and Stx2g in only 1 of 4 positive strains $(25 \%)$. The Stx $2 \mathrm{f}$ variant was not detected in any of the six Stx2f-producing strains that were tested. Thirty-three strains producing multiple types of Stx strain were all detected. Four Stx-negative strains were used as controls and false positive reactions were not recorded (Table 1). The results obtained with the Rida Screen Verotoxin ELISA were identical to those obtained with the RIDA Quick Test for Stx-detection (Table 1).

\begin{tabular}{ccccc}
\hline $\begin{array}{c}\text { numbers } \\
\text { of strains }\end{array}$ & $\begin{array}{c}\text { bacterial } \\
\text { species }\end{array}$ & Stx type & $\begin{array}{c}\text { Numbers of strains testing positive for Stx } \\
\text { berocellassay }\end{array}$ & $\begin{array}{c}\text { by Rida Sccreen and } \\
\text { by Rida Quick (\%) }\end{array}$ \\
\hline 1 & S. dysenteriae & Stx1 & $1(100)$ & $1(100)$ \\
1 & S. sonnei & Stx1 & $1(100)$ & $1(100)$ \\
9 & E. coli & Stx1a & $9(100)$ & $9(100)$ \\
5 & E. coli & Stx1c & $5(100)$ & $5(100)$ \\
4 & E. coli & Stx1d & $4(100)$ & $4(100)$ \\
12 & E.coli & Stx2a & $12(100)$ & $12(100)$ \\
6 & E. coli & Stx2c & $6(100)$ & $6(100)$ \\
9 & E. coli & Stx2b & $9(100)$ & $8(88.9)$ \\
7 & E. coli & Stx2d & $7(100)$ & $3(27.3)$ \\
11 & E. coli & Stx2e & $11(100)$ & $1(25.0)$ \\
4 & E. coli & Stx2g & $4(100)$ & $0(0)$ \\
6 & E. coli & Stx2f & $6(100)$ & $33(100)$ \\
33 & E. coli & multiple & $33(100)$ & $0(0)$ \\
4 & E. coli & none & $0(0)$ & \\
\hline
\end{tabular}

Table 1. Types of Stx tested and their percentages detected by Rida Screen Verotoxin Elisa and Immuno-chromotographic RIDA quick.

\subsection{Detection of the 0157 antigen}

The specificity of the assay for the E. coli $\mathrm{O} 157$ antigen was tested with 134 strains belonging to 45 different O-antigen groups of E. coli, including 17 E. coli O157 strains. The RIDA Quick assay detected all E. coli O157 strains tested, irrespective of whether these were STEC or not. Strains belonging to the non-O157 serogroups did not react for the O157 antigen in the Rida Quick assay indicating a specificity of $100 \%$. 


\subsection{Detection of Stx- and the 0157 antigens from EHEC-contaminated food samples}

The sensitivity of the Rida Quick test for detection of Stx and the O157 antigen was analyzed for food samples spiked with different amounts of EHEC strains. Twenty-five-gram portions of retailed ready-to-eat salads were inoculated with different amounts $(<10,10-100$, 100-1000 cfu) with different concentrations of EHEC reference strains belonging to serogroups O26, O103, O111, O145, O157 (Table 2).

\begin{tabular}{|c|c|c|c|c|c|c|c|c|c|}
\hline \multirow[b]{3}{*}{$\begin{array}{l}\text { EHEC- } \\
\text { serotype }\end{array}$} & \multirow[b]{3}{*}{ Stx-Type } & \multicolumn{8}{|c|}{ Numbers of EHEC per $25 \mathrm{~g}$ salad sample inoculated } \\
\hline & & \multicolumn{2}{|c|}{ none } & \multicolumn{2}{|c|}{$\leq 10$} & \multicolumn{2}{|c|}{$10-100$} & \multicolumn{2}{|c|}{$100-1000$} \\
\hline & & $\begin{array}{c}\text { Rida } \\
\text { screen }^{a}\end{array}$ & $\begin{array}{l}\text { Rida- } \\
\text { Quick }\end{array}$ & $\begin{array}{l}\text { Rida- } \\
\text { Screen }\end{array}$ & $\begin{array}{l}\text { Rida- } \\
\text { Quick }\end{array}$ & $\begin{array}{l}\text { Rida- } \\
\text { Screen }\end{array}$ & $\begin{array}{l}\text { Rida- } \\
\text { Quick }\end{array}$ & $\begin{array}{l}\text { Rida- } \\
\text { Screen }\end{array}$ & $\begin{array}{l}\text { Rida- } \\
\text { Quick }\end{array}$ \\
\hline O157:H7b & Stx $1 a+$ Stx $2 a$ & 0.015 & - & 3.448 & $4+$ & 9.992 & $4+$ & 9.992 & $4+$ \\
\hline O26:H11 & Stx1a & 0.001 & - & 0.727 & $3+$ & 2.655 & $4+$ & 9.993 & $4+$ \\
\hline O103:H2 & Stx1a & 0.015 & - & 9.983 & $4+$ & 9.983 & $4+$ & 9.983 & $4+$ \\
\hline $\mathrm{O} 145: \mathrm{H} 28$ & Stx $2 a$ & 0.003 & - & 2.932 & $4+$ & 3.475 & $4+$ & 3.402 & $4+$ \\
\hline O111:H8 & Stx1a & 0.001 & - & 3.269 & $4+$ & 3.303 & $4+$ & 9.995 & $4+$ \\
\hline O118:H16 & Stx2a & 0.007 & - & 9.986 & $3+$ & 9.986 & $4+$ & 9.986 & $4+$ \\
\hline O121:H19 & Stx $2 a$ & 0.007 & - & 2.911 & $4+$ & 3.479 & $4+$ & 3.278 & $4+$ \\
\hline
\end{tabular}

a) Extinction values at OD450 $\mathrm{nm}$ for the Rida Screen were calculated as described previously (Beutin et al. 2007) b) the O157 antigen was detected as 4+ in all concentrations with the Rida-Quick test

Table 2. Detection of Shiga toxins produced by EHEC strains from spiked ready-to-eat salad samples.

Spiked and unspiked control $25 \mathrm{~g}$ salad samples were each homogenized in $225 \mathrm{ml}$ BRILABroth and the homogenates were grown aerobically for six hours at $37^{\circ} \mathrm{C}$ for EHEC enrichment (Tzschoppe 2010). After, $1 \mathrm{ml}$ of BRILA broth enrichment culture was inoculated into $5 \mathrm{ml}$ of $\mathrm{mTSB}+$ Mitomycin (Klie et al. 1997) and incubated at $37^{\circ} \mathrm{C}$ for a further 18 hours. The mTSB+ Mitomycin C cultures were examined for the presence of Stx and O157 antigens with the Rida Screen and the Rida Quick assay. Unspiked salad samples were taken as negative controls. In all the spiked salad samples tested we detected positive reactions (Table 2). No false positive reaction was found. The results obtained with O157:H7inoculated salad samples are shown in Figure 3.

\section{Discussion}

The RIDA Quick was found suitable for the routine screening of bacterial isolates and for the detection of all Stx subtypes tested, except for Stx2f. All other Stx-variants were easily detectable with this assay. Negative Stx detection results obtained for some Stx2b, Stx2d, Stx2e and Stx2g strains are probably due to the poor Stx production, which is below the detectable level for the serological assays.

The results obtained with the Rida Screen Verotoxin ELISA were identical to those obtained with the RIDA Quick Test for Stx-detection (Table 1). As both tests are from the same producer, it is possible that the antibodies used for Stx detection are the same in both assays. 
All Stx types except Stx2f were detectable with the RIDA Quick assay and the Rida Screen ELISA. Stx $2 \mathrm{f}$ is genetically the most distant from all other toxins of the stx 2 group (Persson et al. 2007; Schmidt et al. 2000). It is therefore possible that the Stx2-specific antibody used for the RIDA Quick and the RidaScreen assay does not react with the Stx2f variant toxin. The nucleotide sequence of Stx2f is sufficiently divergent (Fig. 2) that it is not detected by many Stx2-specific PCR primers (Schmidt et al. 2000), nor in Real time Stx- detection kits for Stx2 (Beutin et al. 2009). Some Stx2b, Stx2d, Stx2e and Stx2g strains did not produce enough toxins to be detectable by both Rida Screen and RIDA Quick (Beutin et al. 2007; Beutin et al. 2007a; Beutin et al. 2008). The Stx types Stx1, Stx2a and Stx2c that are associated with typical EHEC strains (Nataro and Kaper 1998) were detected in all the tested strains.

The first results with EHEC inoculated food samples indicate that the RIDA Quick assay is suitable for the screening of food samples such as ready-to-eat salads. These kinds of vegetable food samples are characterized by their high level of contamination $\left(10^{6}-10^{7} \mathrm{cfu} /\right.$ g) with Pseudomonas and Enterobacteriaceae from their own natural flora (Klepzig et al. 1999; Tzschoppe 2010). Low numbers (<10 cfu / 25g) of EHEC were still detectable in these inoculated food samples after enrichment (Fig. 3). The choice of enrichment medium and procedure was found to be important. The presence of an enhancer (Mitomycin C) in the growth medium is needed for the best results (data not shown). Further tests on food samples contaminated naturally with STEC / EHEC are needed to evaluate the suitability of the Rida Quick assay for the routine examination of food samples.

\section{References}

Bettelheim, K.A. and Beutin, L. (2003) Rapid laboratory identification and characterization of verocytotoxigenic (Shiga toxin producing) Escherichia coli (VTEC/STEC). Journal of Applied Microbiology 95, 205-217.

Beutin, L., Steinruck, H., Krause, G., Steege K., Haby, S., Hultsch, G. and Appel B. (2007) Comparative evaluation of the Ridascreen ((R)) Verotoxin enzyme immunoassay for detection of Shiga-toxin producing strains of Escherichia coli (STEC) from food and other sources. J. Appl. Microbiol. 102, 630-639.

Beutin, L., Martin, A., Krause, G., Steege, K., Haby, S., Pries, K., Albrecht, N., Miko, A. and Jahn, S. (2010) Ergebnisse, Schlussfolgerungen und Empfehlungen aus zwei Ringversuchen zum Nachweis und zur Isolierung von Shiga (Vero) Toxin bildenden Escherichia coli (STEC) aus Hackfleischproben [Results, conclusions, and recommendations of two ring trials for the detection and isolation of shiga (Vero) toxin producing Escherichia coli (STEC) from minced beef samples]. Journal für Verbraucherschutz und Lebensmittelsicherheit 5, 21-34.

Beutin, L. (2006) Emerging Enterohaemorrhagic Escherichia coli, Causes and Effects of the Rise of a Human Pathogen. J. Vet. Med. B Infect. Dis. Vet. Public Health 53, 299-305.

Beutin, L., Jahn, S. and Fach, P. (2009) Evaluation of the 'GeneDisc' real-time PCR system for detection of enterohaemorrhagic Escherichia coli (EHEC) O26, O103, O111, O145 and O157 strains according to their virulence markers and their O- and H-antigenassociated genes. J Appl Microbiol 106, 1122-1132.

Beutin, L., Kruger, U., Krause, G., Miko, A., Martin, A. and Strauch, E. (2008) Evaluation of major types of Shiga toxin 2e producing Escherichia coli present in food, pigs and in 
the environment as potential pathogens for humans. Appl Environ Microbiol. 74: $4806-4816$.

Beutin, L., Miko, A., Krause, G., Pries, K., Haby, S., Steege, K. and Albrecht, N. (2007a) Identification of human-pathogenic strains of Shiga toxin-producing Escherichia coli from food by a combination of serotyping and molecular typing of Shiga toxin genes. Appl Environ Microbiol 73, 4769-4775.

Beutin, L., Zimmermann, S. and Gleier, K. (1996) Rapid detection and isolation of Shiga-like toxin (verocytotoxin)-producing Escherichia coli by direct testing of individual enterohemolytic colonies from washed sheep blood agar plates in the VTEC-RPLA assay. Journal of Clinical Microbiology 34, 2812-2814.

Beutin, L., Zimmermann, S. and Gleier, K. (2002) Evaluation of the VTEC-screen "Seiken" test for detection of different types of Shiga toxin (verotoxin)-producing Escherichia coli (STEC) in human stool samples. Diagnostic Microbiology and Infectious Disease 42, $1-8$.

Brooks, J.T., Sowers, E.G., Wells, J.G., Greene,K.D., Griffin, P.M., Hoekstra, R.M. and Strockbine, N.A. (2005) Non-O157 Shiga toxin-producing Escherichia coli infections in the United States, 1983-2002. The Journal of Infectious Diseases 192, 1422-1429.

Burk, C., Dietrich, R., Acar, G., Moravek, M., Bulte, M. and Martlbauer, E. (2003) Identification and characterization of a new variant of Shiga toxin 1 in Escherichia coli ONT:H19 of bovine origin. Journal of Clinical Microbiology 41, 2106-2112.

Caprioli, A., Morabito, S., Brugère, H. and Oswald, E. (2005) Enterohaemorrhagic Escherichia coli: emerging issues on virulence and modes of transmission. Vet. Res. 36, 289-311.

Eblen, D. R. (2007) Public Health Importance of non-O157 Shiga-Toxin producing Escherichia coli (non-O157 STEC) in the US food supply. ed. United States Department of Agriculture pp. 1-48.

ECDC, EFSA (2011) Shiga toxin/verotoxin-producing Escherichia coli in humans, food and animals in the EU/EEA, with special reference to the German outbreak strain STEC O104. ed. ECDC and EFSA. http://www.efsa.europa.eu/en/supporting/doc/166e.pdf

EFSA. (2007) Scientific opinion of the panel on biological hazards on a request from EFSA on monitoring of verotoxigenic Escherichia coli (VTEC) and identification of human pathogenic types. The EFSA Journal 579, 1-61.

Feng, P.C., Jinneman, K., Scheutz, F. and Monday, S.R. (2011) Specificity of PCR and Serological Assays in the Detection of Escherichia coli Shiga Toxin Subtypes. Appl Environ Microbiol 77, 6699-6702.

Frank, C., Faber, M., Askar, M., Bernard, H., Fruth, A., Gilsdorf, A., Hohle, M., Karch, H., Krause, G., Prager, R., Spode, A., Stark, K. and Werber, D. (2011) Large and ongoing outbreak of haemolytic uraemic syndrome, Germany, May 2011. Euro. Surveill 16.

Friedrich, A.W., Bielaszewska, M., Zhang, W.L., Pulz, M., Kuczius, T., Ammon, A. and Karch, H. (2002) Escherichia coli harboring Shiga toxin 2 gene variants: frequency and association with clinical symptoms. J. Infect. Dis. 185, 74-84.

Friedrich, A.W., Borell, J., Bielaszewska, M., Fruth, A., Tschape, H. and Karch, H. (2003) Shiga toxin 1c-producing Escherichia coli strains: phenotypic and genetic characterization and association with human disease. Journal of Clinical Microbiology $41,2448-2453$.

Gyles, C.L. (2007) Shiga toxin-producing Escherichia coli: an overview. J Anim Sci 85, E45-E62. 
Herold, S., Karch, H. and Schmidt, H. (2004) Shiga toxin-encoding bacteriophages--genomes in motion. Int J Med Microbiol 294, 115-121.

Hussein, H.S. and Bollinger, L.M. (2008) Influence of selective media on successful detection of Shiga toxin-producing Escherichia coli in food, fecal, and environmental samples. Foodborne. Pathog. Dis 5, 227-244.

Jahn, S. and Beutin, L. (2009) Evaluation Of The "GeneDisc" Real-Time PCR System For Detection Of Major EHEC Type Strains From different Food matrices (minced meat, "Mettwurst", salami and raw milk). Buenos Aires, Argentina: VTEC 2009. Book of Abstracts

Jahn, S., Weber, H. and Beutin, L. (2008) Comparison of enzyme immunoassay and quantitiver real time PCR as proof of Shigatoxin producing Escherichia coli (STEC) in mincemeat. Journal fur Verbraucherschutz und Lebensmittelsicherheit-Journal of Consumer Protection and Food Safety 3, 385-395.

Karmali, M.A., Gannon, V. and Sargeant, J.M. (2010) Verocytotoxin-producing Escherichia coli (VTEC). Vet Microbiol 140, 360-370.

Karmali, M.A., Mascarenhas, M., Shen, S., Ziebell, K., Johnson, S., Reid-Smith, R., IsaacRenton, J., Clark, C., Rahn, K. and Kaper, J.B. (2003) Association of Genomic O Island 122 of Escherichia coli EDL 933 with Verocytotoxin-Producing Escherichia coli Seropathotypes That Are Linked to Epidemic and/or Serious Disease. Journal of Clinical Microbiology 41, 4930-4940.

Klepzig, I., Teufel, P., Schott, W. and Hildebrandt, G. (1999) Auswirkungen einer Unterbrechung der Kühlkette auf die mikrobiologische Beschaffenheit von vorzerkleinerten Mischsalaten. Archiv für Lebensmittelhygiene 50, 95-104.

Klie, H., Timm, M., Richter, H., Gallien, P., Perlberg, K.W. and Steinruck, H. (1997) [Detection and occurrence of verotoxin-forming and/or shigatoxin producing Escherichia coli (VTEC and/or STEC) in milk]. Berl Munch. Tierarztl. Wochenschr 110, 337-341.

Konowalchuk, J., Speirs, J.I. and Stavric, S. (1977) Vero response to a cytotoxin of Escherichia coli. Infect Immun 18, 775-779.

Kuczius, T., Bielaszewska, M., Friedrich, A.W. and Zhang, W. (2004) A rapid method for the discrimination of genes encoding classical Shiga toxin (Stx) 1 and its variants, Stx1c and Stx1d, in Escherichia coli. Mol Nutr Food Res 48, 515-521.

Leung, P.H.M., Peiris, J.S.M., Ng, W.W.S., Robins-Browne, R.M., Bettelheim, K.A. and Yam, W.C. (2003) A Newly Discovered Verotoxin Variant, VT2g, Produced by Bovine Verocytotoxigenic Escherichia coli. Applied and Environmental Microbiology 69, 75497553.

Martin, A. and Beutin, L. (2011) Characteristics of Shiga toxin-producing Escherichia coli from meat and milk products of different origins and association with food producing animals as main contamination sources. Int J Food Microbiol 146, 99-104.

McGannon, C.M., Fuller, C.A. and Weiss, A.A. (2010) Different classes of antibiotics differentially influence shiga toxin production. Antimicrobial Agents and Chemotherapy 54, 3790-3798.

Melton-Celsa, A.R., Kokai-Kun, J.F. and O'Brien, A.D. (2002) Activation of Shiga toxin type $2 \mathrm{~d}(\mathrm{St} \times 2 \mathrm{~d}$ ) by elastase involves cleavage of the C-terminal two amino acids of the A2 peptide in the context of the appropriate B pentamer. Mol. Microbiol 43, 207-215. 
Miko, A., Pries, K., Haby, S., Steege, K., Albrecht, N., Krause, G. and Beutin, L. (2009) Assessment of Shiga toxin-producing Escherichia coli isolates from wildlife meat as potential pathogens for humans. Appl Environ Microbiol 75, 6462-6470.

Muthing, J., Schweppe, C.H., Karch, H. and Friedrich, A.W. (2009) Shiga toxins, glycosphingolipid diversity, and endothelial cell injury. Thromb Haemost. 101, 252264.

Nataro, J.P. and Kaper, J.B. (1998) Diarrheagenic Escherichia coli. Clinical Microbiology Reviews 11, $142 \mathrm{ff}$.

Paton, J.C. and Paton, A.W. (2003) Methods for detection of STEC in humans. An overview. Methods Mol Med 73, 9-26.

Persson, S., Olsen, K.E., Ethelberg, S. and Scheutz, F. (2007) Subtyping method for Escherichia coli shiga toxin (verocytotoxin) 2 variants and correlations to clinical manifestations. J Clin Microbiol 45, 2020-2024.

Pierard, D., Muyldermans, G., Moriau, L., Stevens, D. and Lauwers, S. (1998) Identification of new verocytotoxin type 2 variant B-subunit genes in human and animal Escherichia coli isolates. J Clin Microbiol 36, 3317-3322.

Riley, L.W., Remis, R.S., Helgerson, S.D., McGee, H.B., Wells, J.G., Davis, B.R., Hebert, R.J., Olcott, E.S., Johnson, L.M., Hargrett, N.T., Blake, P.A. and Cohen, M.L. (1983) Hemorrhagic Colitis Associated with A Rare Escherichia-Coli Serotype. New England Journal of Medicine 308, 681-685.

Scheutz, F. and Strockbine, N. A. (2005) Genus I. Escherichia. In Bergey's Manual of Systematic Bacteriology ed. Garrity,G.M., Brenner,D.J., Krieg,N.R. and Staley,J.T. pp. 607-624. Springer.

Schmidt, H., Scheef, J., Morabito, S., Caprioli, A., Wieler, L.H. and Karch, H. (2000) A new Shiga toxin 2 variant (Stx2f) from Escherichia coli isolated from pigeons. Applied and Environmental Microbiology 66, 1205-1208.

Schmidt, H. (2001) Shiga-toxin-converting bacteriophages. Research in Microbiology 152, 687695.

Shimizu, T., Ohta, Y. and Noda, M. (2009) Shiga toxin 2 is specifically released from bacterial cells by two different mechanisms. Infect Immun. 77, 2813-2823.

Tzschoppe, M. (2010) Untersuchungen zur Kontamination von pflanzlichen, für den Rohverzehr vorgesehenen, Lebensmitteln mit pathogenen, insbesondere ShigaToxin-bildenden Escherichia coli. pp. 1-119. Diploma-Thesis: Beuth Hochschule für Technik, Federal Institute for Risk Assessment, Berlin, Germany.

Willford, J., Mills, K. and Goodridge, L.D. (2009) Evaluation of three commercially available enzyme-linked immunosorbent assay kits for detection of Shiga toxin. J Food Prot 72, 741-747.

Wong, C.S., Jelacic, S., Habeeb, R.L., Watkins, S.L. and Tarr, P.I. (2000) The risk of the hemolytic-uremic syndrome after antibiotic treatment of Escherichia coli O157:H7 infections. N Engl. J Med 342, 1930-1936. 


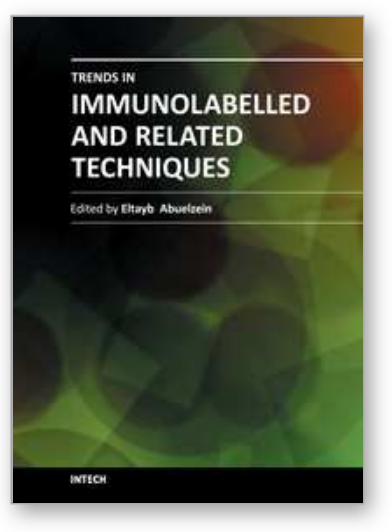

\author{
Trends in Immunolabelled and Related Techniques \\ Edited by Dr. Eltayb Abuelzein
}

ISBN 978-953-51-0570-1

Hard cover, 360 pages

Publisher InTech

Published online 27, April, 2012

Published in print edition April, 2012

The book is coined to provide a professional insight into the different trends of immunoassay and related techniques. It encompasses 22 chapters which are grouped into two sections. The first section consists of articles dealing with emerging uni-and-multiplex immunolabelled methods employed in the various areas of research. The second section includes review articles which introduce the researchers to some immunolabelled techniques which are of vital significance such as the use of the conjugates of the Staphylococcus aureus protein "A" and the Streptococcus Spps. protein "G" in immunolabelled assay systems, the use of bead-based assays and an overview on the laboratory assay systems. The book provides technological innovations that are expected to provide an efficient channel for developments in immunolabelled and related techniques. It is also most useful for researchers and post-graduate students, in all fields, where immunolabelled techniques are applicable.

\title{
How to reference
}

In order to correctly reference this scholarly work, feel free to copy and paste the following:

Ylanna Burgos and Lothar Beutin (2012). Evaluation of an Immuno-Chromatographic Detection System for Shiga Toxins and the E. coli 0157 Antigen, Trends in Immunolabelled and Related Techniques, Dr. Eltayb Abuelzein (Ed.), ISBN: 978-953-51-0570-1, InTech, Available from: http://www.intechopen.com/books/trendsin-immunolabelled-and-related-techniques/evaluation-of-an-immuno-chromatographic-detection-system-forshiga-toxins-and-e-coli-0157-antigen

\section{INTECH}

open science | open minds

\section{InTech Europe}

University Campus STeP Ri

Slavka Krautzeka 83/A

51000 Rijeka, Croatia

Phone: +385 (51) 770447

Fax: +385 (51) 686166

www.intechopen.com

\section{InTech China}

Unit 405, Office Block, Hotel Equatorial Shanghai

No.65, Yan An Road (West), Shanghai, 200040, China

中国上海市延安西路65号上海国际贵都大饭店办公楼405单元

Phone: +86-21-62489820

Fax: $+86-21-62489821$ 
(C) 2012 The Author(s). Licensee IntechOpen. This is an open access article distributed under the terms of the Creative Commons Attribution 3.0 License, which permits unrestricted use, distribution, and reproduction in any medium, provided the original work is properly cited. 